\title{
An Analysis of Speech Acts Used in English Teaching
}

\author{
Nur Indah Sari \\ Program Studi Pendidikan Bahasa Inggris, Fakultas Keguruan dan Ilmu Pendidikan \\ Universitas Widya Gama Mahakam, Indonesia \\ Jl. KH. Wahid Hasyim No. 28 RT.007 Kota Samarinda, Provinsi Kalimantan Timur \\ nurindahsari2261@gmail.com
}

\begin{abstract}
:
This study focused on analyzing speech acts and its forces performed by the English teacher in EF (English First) Samarinda. This study is descriptive study using qualitative approach. There are two teachers as the subjects of the data. The data of the study are the utterances performed by the English teachers. The main instrument of the study is the researcher herself with the help of audio-video recorder during the data collection.

In this study, the researcher uses Searle's theory about types of speech acts. The findings show that 1) there are four kinds of speech acts performed by the teacher during teaching and learning process, those were representative, commissive, directive and expressive, 2) the most frequently speech act performed by the teachers is directive speech act while the least speech act performed is commissive. The directive speech act occurrs as the most speech act performed by the teacher because they want the students to be more active and can contribute more during the teaching and learning process.
\end{abstract}

Keywords: Speech Act, Teaching and Learning Process, Utterances

\section{Introduction}

As the basic unit of language, speech acts are the central for conducted an effective communication since they allow human to perform various kinds of behavior such apologizing, thanking, commanding, requesting, and so on. [12] described speech act theory as a subfield of pragmatics deal with the ways in which phrases can be used not solely to present evidences but also to take out actions. According to [21] speech act are actions that performed an utterance such as requesting, commanding, questioning or informing. Speech acts, the basic part of language that allow people to perform such huge functions including affirming, asserting, blaming, concluding, explaining, informing, notifying, praising and other. The phenomenon mentioned before may happen everywhere, for example in the teaching and learning process.

Considering that communication exists in teaching and learning process and it also involves a lot of interactions where the teacher produced a number of expressions, especially during language classes. Using speech acts theory determine how the process of teaching and learning will occur. [3] emphasizes that the language used by the teacher (speech acts) is primarily important as it supports and improves learning. Using proper speech acts will result in a successful process of teaching and learning.

In this case, the researcher want to conduct a research related to problem above the above, namely speech act. Speech act is a theory which introduced by J.L Austin in 1962 and then developed by J.R Searle in 1969. Another reason for conducting this research is because when the teacher interacts with students, the teacher must be able to speak correctly, so that students can understand the intentions of the speech conveyed by the teacher and the learning process can run well. This is in the line with [13] states that suitable language in teaching and learning activity is the most important thing that influences the teachers' success in reaching the goal in teaching and learning itself. [14] added that the several of speech acts have significant role in leading a successful interpersonal communication particularly in the process of teaching and learning English. Speech acts performed by the teacher has the intent and purpose. Sometimes the intentions and purposes are not conveyed directly. Speeches are delivered through suggestions so the recipient must be able to understand the speech.

According to Levinson $(1983,2008)$ pragmatics refers to the study of grammatical or encoded relationships between language and context. [5] states that pragmatics is about how language 
is used as a tool to create a meaningful communication by considering the situation and the context use. There are number of explanation of pragmatics definition, but in general, some experts stated that pragmatics is the study of language meaning based on its context. Moreover, Yule $(1996,2010)$ describe pragmatics as the study of the speakers mean. He also added that pragmatics have four main areas which have to be concerned. First, pragmatics is concerned with the study of utterance meanings as communicated by the speaker and interpreted by the listener. In this context, pragmatics analyze the speech given by the speaker and how the listener interprets it. The focus on pragmatic is on the utterance's meaning and not simply the meaning of the sentence. There are some scopes studies in the field of pragmatics. They include deixis, cooperative principle, implication, presupposition, and speech acts.

According to [1] and [20] Speech Acts theory said that the action performed when an utterance is produced can be analyzed into three different levels namely locutionary, illocutionary, and perlocutionary. [14] states that speech acts as the basic communication has the important role in teaching and learning process. He classifies speech acts into five categories namely representatives, directives, commisives, declaratives and expressives. Locutionary act is a literal meaning of a sentence, a production of utterances with a certain intended structure, meaning, and reference. [6] states that locution is the basic of utterances, or producing a meaning linguistic expression. Illocutionary act is the act of saying something that is committed with the intention of the speaker by pronouncing a sentence, that is called as illuctionary force [20]. The forces can be in the form of asking, stating, questioning, promising, ordering, apologizing, threatening, and requesting. [14] stated that the illocutionary act is an act performed in saying something. That is, illocutionary act can be clarified as using a sentence to perform a function. Perlocutionary act refers to the effect this utterance has on the thoughts or action of the other person. According to [1] perlocutionary act is the effect of an utterance.

Some researchers had conducted the same study. The researcher were Merdana et al (2013), Widya (2017), and Swandewi et al (2018). In [10]'s study, they analyzed the teachers and the student's speech acts. The most produce speech acts by the teachers was directives speech acts, while the students' speech acts were mostly representatives. Then, in [19]'s study, she was analyzed the speech act in STKIP YDB Lubuk Alung, one of the University in Padang Pariaman Regency. She found that the most frequently speech acts performed were directives $(53 \%)$, while the least frequent illocutionary acts went to commissives $(5 \%)$. The frequent use of directives shows that the lecturer seemed to be aware of their status as a lecturer which was believed to be more powerful than her students. [16]'s study was conducted in SMA Negeri 2 Banjar. They found four speech acts during the data analyzed. The most frequent speech act performed by the teachers is directive speech act. It occurred when the teachers tried to give questions, request something, give command, interrupt, invite, prohibit, motivate give suggestion and remind. In their study, this speech acts presented utterances about 133 utterances with the percentage about $62 \%$.

Those researches showed that the teaching and learning process cannot be separated by the existence of speech acts. Every utterances said by the teachers has several functions to make the classroom interaction to be more active. That is, the researcher also interested to do the same study to find out every utterances said by the teachers also the function of those utterances. The researcher also want to find out what kind of speech acts that mostly performed by the teachers during the teaching and learning process. The study was conducted in one of the English Course place, the name of the English Course is English First, and it was located in Samarinda. 


\section{Methodology}

This study was conducted using qualitative approach with descriptive design. There are some typical examples in qualitative data, those are including observation notes, interview transcripts, literary texts, minutes of meetings, historical records, memos and recollections, documentary film [17]. This study is using descriptive methods. This design is used to describe, explain and analyze the phenomenon that occurred behind the data. Walliman $(2011,2018)$ stated this design is based on observation as a means of data collection. It tries to examine situations to determine what the norm is, that is, what can be predicted under the same circumstances to happen again. This study analyzed the speech produce by the teachers of English First Samarinda. The subjects of this study were from the English First Samarinda which consist of two teachers. This study is qualitative, thus the researcher herself act as the primary instrument. The researcher plays role as an analyzer, implementer of data collection and data analysis, data interpreter and finally as a discoverer of the research result [4].

The data on this study were collected using [9]. Those were recording the English teaching and learning activities in the classroom, transcribing the dialog from the recording into the written form, selecting the collected data from the recording, input the collected data into the data sheet. In doing this study the researcher will be collecting data using camera and audio recorder to record teacher's utterances in the classroom. Qualitative data is useful when the data collected from the same setting need to be supplemented, validated or illuminated [11] The data were analyzed using [11] interactive model of data analysis. That is, the data were analyzed through three activities they are data condensation, data display, drawing and conclusion drawing/verification to make the data stronger.

\section{Findings and Discussion Finding}

These data findings are related to the types of speech acts in terms of illocutionary acts performed by the teacher during the teaching and learning process at English First Samarinda. [15] classifies speech acts into five categories, i.e. representatives, directives, expressives, commisives, and declarations. However, during the observation, the findings show that there were only four types of speech acts performed by the teacher, namely representatives, directives, commisives and expressives and it will be presented in the table below.

Table 1. The Speech Acts Occurrences during the Teaching and Learning Process

\begin{tabular}{|c|c|c|c|c|}
\hline \multirow{2}{*}{ No. } & \multirow{2}{*}{$\begin{array}{c}\text { Classification of } \\
\text { Searle's Speech Acts } \\
\text { (The Illocutionary } \\
\text { Act) }\end{array}$} & \multirow{2}{*}{ Illocutionary Forces } & \multicolumn{2}{|c|}{ Frequency } \\
\hline & & & Meeting 1 & Meeting 2 \\
\hline \multirow[t]{7}{*}{1.} & Representative & 1. Stating & 19 & 12 \\
\hline & & 2. Explaining & 46 & 33 \\
\hline & & 3. Informing & 18 & 22 \\
\hline & & 4. Confirming & 47 & 29 \\
\hline & & 5. Agreeing & 9 & 4 \\
\hline & & $\begin{array}{l}\text { A. Agreeing } \\
\text { 6. Disagreeing }\end{array}$ & 2 & 2 \\
\hline & & Total & 141 & 102 \\
\hline \multirow[t]{5}{*}{2.} & Directive & 1. Asking & 125 & 116 \\
\hline & & 2. Ordering & 38 & 29 \\
\hline & & 3. Suggesting & 3 & 5 \\
\hline & & 4. Warning & 4 & - \\
\hline & & Total & 170 & 150 \\
\hline \multirow[t]{2}{*}{3.} & Commisive & 1. Refusing & 4 & - \\
\hline & & Total & 4 & - \\
\hline \multirow[t]{2}{*}{4.} & Expressive & 1. Thanking & 1 & 11 \\
\hline & & 2. Praising & 4 & 12 \\
\hline
\end{tabular}




\begin{tabular}{|c|c|c|}
\hline 3. Apologizing & 1 & 4 \\
\hline Total & 6 & 27 \\
\hline $\begin{array}{r}\text { Total of illocutionary act occurrences } \\
\end{array}$ & 317 & 279 \\
\hline Total of illocutionary act occurrences in both meeting & & \\
\hline
\end{tabular}

The number of occurrences can be seen as directives speech acts being the most speech acts performed by the teacher with the total of 320 utterances, following by representatives speech act with 242 utterances, then expressives speech acts with 33 utterances and the least speech acts performed by the teacher was commisives speech act with only 4 utterances found during the teaching and learning process.

\section{a. Representatives}

Representatives speech act are speech acts which represent what the speaker believes and does not believe. In this research, representatives were revealed as the second-highest significance performed by the teacher during the teaching and learning process. Here is one of the examples of confirming:

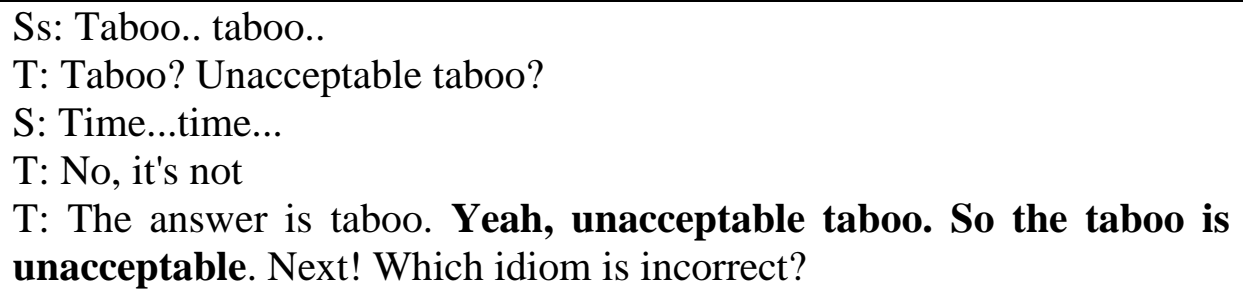

$M-1 / 70 / 25: 38-26: 05$

In this case, the teacher asked the students about collocation. She gave her students a writing section. The students have to choose which one of the following words that have been provided by the teacher is the answer. After several attempts to answer the question, the students finally found the right answer. Then, the teacher confirmed that students' answer was correct. The teacher produced the confirming illocutionary force by uttering the right sentence to the students. She uttered the utterances affirmatively.

\section{b. Directives}

Directives are those kinds of speech acts used by the speaker to get the hearer to do something or to take some certain actions. During the teaching and learning process, out of 596 data, directives appeared with 320 acts. It became the most frequently speech acts performed by the teachers. The example of directive speech act can be shown below.

\section{T: Okay, 3:50 I want it to finish before 4:00. Okay?}

\section{M-1/31/13:03}

At the moment, the teacher gave the student a reading activity. The teacher, here, employed the illocutionary force of ordering. The teacher wanted her students to do something; that is reading. The teacher ordered the students to do something using direct speech acts because in classroom instruction the teacher tends to have higher position than the students. However, in this example, the teacher employed the word "okay" to soften the order. 


\section{c. Commisives}

Commisives are those kinds of speech acts performed by speakers to commit themselves to future actions. In this study, commissives appeared in four utterances. The only illocutionary force of commissives found in this study was refusing and the following is the example of commissives.

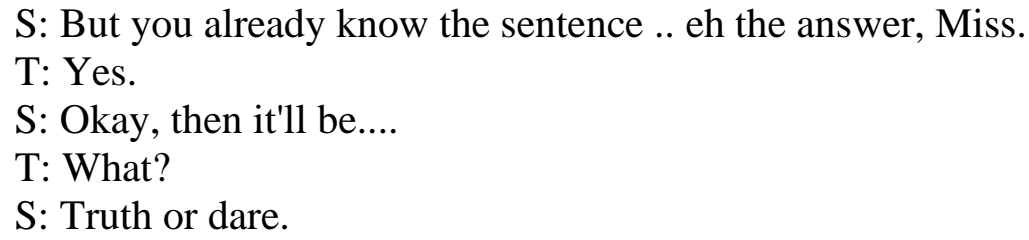

M-1/209/1:07:31

Ss: Yes...!!!

T: No. Because I know you are going to ask something that is ... not proper in the classroom, okay. So, found some sentence it's start 'a' and 'an'. What is it?

M-1/210/1:07:40

This was the case where the teacher makes the doll jump. The rule before said the one who made the doll jump will get a penalty. So the students wanted the teacher to follow the rule. However, because the teacher already knows the answer, she did not accept what the students have requested. The phrase "no" meaning that the teacher could not grant what the student want. The teacher also added the reason why she did not want to because the student will ask some not proper questions to the teacher.

\section{d. Expressives}

Expressives are the psychological expressions regarding to the speaker's feeling [20]. Expressives can be in the form of thanking, congratulating, apologizing, welcoming etc. Here is the example of expressive.

S: They accomplish this book for the first time in 1995.

T: Time. Alright, thank you very much. $\mathrm{D}$, Sharon?

M-2/105/36:38

The teacher's utterance above is included in the expressive because it expresses the impression or feelings of the speaker towards the proposition. The teacher expressed her appreciativeness to the students because the student had answered the questions correctly. The teacher utterance is classified as thanking. It is indicated by the use of the expression "thank you very much". All of the acts of thanking in this research were performed by involving the expression of "thank you".

\section{Discussion}

In this study, Directives became the most dominant speech acts used by the teachers and it similar to some previous study by Merdana et al. (2013), Widya (2017) and Swandewi et al. (2018), in their study Directives speech act was also become the most frequent speech act uttered by the teachers. According to the data from the video recording, directives speech acts become the most frequent speech act performed by the teachers because the teachers often asked the students to do something during the English teaching and learning activities. This is in line with the concept of directive speech acts by [15] that is to make the hearer to take some 
action. This was also found in previous studies by[16] they argue that this speech act is used so that students are able to contribute actively in teaching and learning activities and also get more interaction between teachers and students. Asking become the most dominant forces in directive speech act performed by the teachers found during the data analysis because in teaching and learning process involved question (asking) and answer activities. This is supported by Merdana et al., (2013), Widya (2017) and Swandewi et al. (2018).

In addition, [10] stated that, since the teacher was the one who controlled and managed the class, Directive speech acts became the most frequently performed by the teacher. They also stated that the reason was because it has several functions. The functions are to check the students' knowledge of certain information, to check the students' understanding of certain information, and to ask the students' ability to do something. Meaning that the teachers have power to maintain the class.

In contrast, Commissives were the least frequently used speech acts performed by the teacher throughout the research with only one forces found namely refusing. Refusing is one of the forces of commisives speech acts according to the theory by [2] and [20]. There were four utterances of refusing found in this study. The teacher uttered the act of refusing because she does not want to accept what the students have requested due to inappropriate for the class. The act of refusing in this study marked with a phrase "no". This is supported by the theory from [6]. This finding was different from the previous study by [16]. In their study, the only forces found was promising with the marked of "I will" uttered by the speaker.

Meanwhile, declaratives were not performed at all by the teachers in the teaching and learning process. This is also similar with the studies by Merdana et al., (2013), Widya (2017) and Swandewi et al. (2018) which declaratives speech acts were also not found in the findings. The reason why declaratives were not performed by the teachers because this speech act is not related in teaching and learning field. This statement is supported by [2]'s theory, said that declaratives only include sacking a worker, performing a marriage, and sentencing a criminal. [2] also added that declarative is speech act which has an effect in the real world, in bringing about the state to which it refers, it can hardly occur within literary discourse except as a pseudo-speech act, as when characters marry, or are sent to prison.

There are always questions and answers between teachers and students during the teaching and learning activities. The Directives speech acts are more emphasized by the teacher because, essentially, they want to know the abilities of their students, whether students understand what has been taught, whether the information provided by the teacher can be point out by the students. According to the findings, the teachers were also performed another speech acts such as Representatives, Commissives and Expressives. The teachers performed such speech acts in order to make the teaching and learning process can run well and not ambiguous.

\section{Conclusion}

Concerning with the objective of the research which was types of speech acts performed by the English teacher. The reseacher concluded that there were four types of speech acts found performed by the teachers during the English teaching and learning process in English First (EF) Samarinda. Those were, representative, directive, commisive and expressive. Regarding to illocutinary forces, there were lots of forces occured in the teaching and learning process. For representative, there were stating, explaining, informing, confirming, agreeing and disagreeing. Asking, ordering, suggesting and warning for directive. Refusing for commisive. And then, for expressive there were thanking, praising and apologizing. Directive became the most dominant speech act carried out in 
teaching and learning process. Directive was the most commonly speech acts performed by teachers. There were 320 utterances included in the directive speech act and those were divided into asking, ordering, suggesting and warning. The teacher used directives to get the learners to take certain activities. Asking became the most dominant speech act force of directives performed by the teacher. There were 241 utterances total of asking out of all speech acts. The use of asking by the teacher enabled the learners to engage in the class more actively. By asking, the teacher could knew the query whether the students comprehend the lessons learned or not.

\section{References}

[1] J.L. Austin, "How To Do Things With Words", London: Oxford University Press, 1962.

[2] E. Black, "Pragmatic Stylistics", Edinburgh: Edinburgh University Press, 2006.

[3] M. Celce-Murcia, "Discourse and Context in Language Teaching", Cambridge: Cambridge University Press, 2000.

[4] L.R. Gay, G.E. Mills, and P. Airasian, "Educational Research: Competencies for Analysis and Applications", Boston: Pearson, 2012.

[5] P. Griffiths, "An Introduction to English Semantics and Pragmatics", Edinburgh: Edinburgh University Press, 2006.

[6] G. Leech, "Principles of Pragmatics" Jakarta: Universitas Indonesia, 1993.

[7] S.C Levinson, "Pragmatics", Cambridge: Cambridge University Press, 1983

[8] S.C Levinson, "Pragmatics", Cambridge: Cambridge University Press, 2008.

[9] J.H. McMillan, and S. Schumacher, "Research in Education: Evidence-Based Inquiry", Harlow: Pearson, 2014.

[10] K.S. Merdana, and A.J.P. N, "An Analysis Of Speech Acts Produced By Elementary School Teachers And Students To Facilitate Teaching and Learning At SDN 10 Pringgasela East Lombok", Jurnal Pendidikan Bahasa Inggris Universitas Pendidikan Ganesha, 1, 2013.

[11] M.B. Miles, A.M. Huberman, and J. Saldana, "Qualitative Data Analysis: A Methods Sourcebook", London: SAGE Publication, Inc, 2014.

[12] R. Nordquist, "Speech-Act Theory", 2019.

[13] M.J. Schleppegrel, "The Language of Schooling A Functional Linguistics Perspective", London: Lawrence Erlbaum Associates, Publishers, 2004.

[14] J.R. Searle, "Speech Acts: An Essay in the Philosophy of Language", London: Cambridge University Press, 1969.

[15] J.R. Searle, "Expressing and Meaning: Studies in the Theory of Speech Acts", Cambridge: Cambridge University Press, 1979.

[16] I.A.N.A. Swandewi, D. Ramendra, and P.A.K. Juniarta, "An Analysis of Speech Acts used by English Teachers in Classroom Teaching and Learning Process At SMA Negeri 2 Banjar", Jurnal Pendidikan Bahasa Inggris Undiksha, 4, 3, 2018.

[17] N. Walliman, "Research Methods: The Basics", London: Routledge, 2011.

[18] N. Walliman, "Research Methods: The Basics", London: Routledge, 2018.

[19] S.O. Widya, "A Pragmatic Analysis of Speech Acts Used by English Lecturers in Languange Teaching at STKIP YDB Lubuk Alung", Jurnal Arbitrer, 4, 2017.

[20] G. Yule, "Pragmatics", Oxford: Oxford University Press, 1996.

[21] G. Yule, "The Study of Language", Cambridge: Cambridge University Press. UK, 2010. 